\title{
SELECTED FACTORS OF DEVELOPMENT IN THE FIELD OF METALLURGIC COMPANIES' MANAGEMENT
}

\author{
Šárka VILAMOVÁ ${ }^{1}$ \\ Vysoká škola podnikání \\ Kamila JANOVSKÁ ${ }^{2}$ \\ Vysoká škola podnikání \\ Roman KOZEL ${ }^{3}$ \\ Vysoká škola báňská-Technická univerzita Ostrava \\ Milan $\mathrm{STOCH}^{4}$ \\ Vysoká škola podnikání
}

\begin{abstract}
The business success in the competitive environment depends very much on efficiency and flexibility of firms. The tense economic situation forces companies to change the perspective of the strategic management and use new opportunities for marketing, management, business integration, networking and offshoring.

This paper presents the results of resources evaluation of the modern management trends application in the field of metallurgy, including the identification of specific areas of metallurgical companies in the context of a differentiated approach to the role of the customer as a potential positive competitiveness factor.
\end{abstract}

\section{KEY WORDS}

Management, Development Trends, Metallurgy Sector, International Market

\section{JEL CLASSIFICATION}

O10, F63, L11, M10

\footnotetext{
${ }^{1}$ Correspondence address: Doc. Ing. Šárka Vilamová, Ph.D., sarka.vilamova@vsp.cz, Vysoká škola podnikání, a. s., Michálkovická 1810/181, 71000 Ostrava - Slezská Ostrava, www.vsp.cz

${ }^{2}$ Correspondence address: Doc. Ing. Kamila Janovská, Ph.D., kamila.janovska@ centrum.cz, Vysoká škola podnikání, a. s., Michálkovická 1810/181, 71000 Ostrava - Slezská Ostrava, www.vsp.cz

${ }^{3}$ Correspondence address: Ing. Roman KOZEL, Ph.D., roman.kozel@vsb.cz , Vysoká škola báňská-Technická univerzita Ostrava, 17. listopadu 15/2172, 70833 Ostrava-Poruba, www.vsb.cz

${ }_{4}$ Correspondence address: Ing. Milan STOCH, Ph.D., milan.stoch@vsp.cz, Vysoká škola podnikání, a. s., Michálkovická 1810/181, 71000 Ostrava - Slezská Ostrava, www.vsp.cz
} 


\section{INTRODUCTION}

Participation of industrial companies in the international market is potentially very profitable activity, although companies cannot expect to be successful immediately after they start international trading. They have to adapt to needs and options of the international market so they can become long-term participants. Due to advancing globalization, the companies have less time to adapt to new market situation and besides, many industrial companies are exposed to international competition, and that is why it is in essence necessary to take part in the international trade.

Europe is a global leader in the fields of metallurgical and in particular steel industry. This sector with a turnover of about 200 billion euro directly employs approximately 400000 highly qualified individuals, produces 200 million tons of steel per annum in more than 500 manufacturing locations in $23 \mathrm{EU}$ Member States, which handles both direct and indirect employment and source of income for millions of European citizens.

However, this sector is currently facing unprecedented challenges not only in Europe, but also at global markets. Several world's economic indicators and market prognosis indicate the need to make a number of changes in the field of metallurgical industry in the near future. The business success in this competitive environment is mostly given by the measure of efficiency and flexibility. Tight economic situation (low profitability, reluctance of banks to lend to industry, growth of energy prices), which occurred as a result of the global crisis, forced the metallurgical enterprises to change their perspective of strategic management and use new opportunities in marketing, management and business integration.

\section{ANALYSIS OF SELECTED INDICATORS OF METALLURGY SECTOR}

Latest economic forecasts indicate that the Eurozone debt crisis is increasingly eroding the real economy. Risk aversion in the financial sector led to further decline in credit offer. This factor consequently acts to reduce economic growth and employment. Investment and private consumption will be suppressed until the return of financial market confidence. But the outlook for most steel producers is relatively favourable.

There are a number of negative factors identified in the world economy within field of metallurgy sector such as:

- increasing cost of capital and the presence of potential risk of credit constraints;

- worldwide reduction in leverage for states, banks, industry and families;

- instability of the euro, its weakening against the U.S. dollar;

- slowing economies of the BRIC countries;

- risk of stagflation;

- sudden slowdown of real demand;

- and fierce competition caused by the overlapping roles of steel plants, service centres and wholesalers.

What are the prognoses for metallurgical industry in individual territories of the world? The economic growth of Brazil is not progressing as expected, but may seize the new opportunities. Russia's accession to the WTO may improve the situation. 
India will continue to try to go forward in its role as an emerging power. China's demand will continue to grow, although at a lower rate than it has until now. The investments of large international manufacturers of steel equipment in the construction of technical equipment, sales and service centres in China and India show, that those countries are trustworthy and indicates where the new business is going to take place. In the long term view the need to release the latent potential of many African countries will arise (WORLDSTEEL, 2013).

China and India will continue to be the key drivers only with a different rate than in the last decade. Middle East and Africa should not be underrated. The crises in Greece or "The Arab spring" could not be predicted. Orders for steel producers decreased due to the fear factor: the concern that banks will be forced to limit loans and the demand in China may therefore fall as well. The future therefore depends on governments, central bankers and state administrations.

Steel suppliers must offer their services globally and organise themselves according to segments; e.g. car parts, building industry, power industry, etc. Manufacture of intermediate products was placed in countries like Brazil, China and Russia. As an example may serve the new joint venture - ThyssenKrupp steel mill in Santa Cruz, Brazil, which produces slabs exclusively for export, 3 million tonnes a year to the steel mill TKS in Mobile, Alabama and 2 million tonnes a year to Duisburg, Germany via Rotterdam (METAL BULLETIN, 2013).

New production capacity will continue to be built especially in low-costs countries and high market demand countries. World steel production will continue its inexorable rise in 2014 despite the downbeat economic prospects. Stabilizing element of global economic development will remain to be Asian markets, primarily China and also some parts of South America.

The year 2014 will be in particular characterized by the efforts to stabilize public finances in the USA and also the economies in developed European countries. It is expected that emerging economies will continue to grow significantly faster than those of the developed countries (METAL BULLETIN, 2013).

The global population should reach 9 billion people in the year 2050. In the context of international relations will demographic development have significant impact not only in terms of availability of global resources such as water, energy or metals, but also in terms of change within supply of goods and on capital markets. Today's emerging markets are going through similar path as the established economies have come in the past 150 years. However, the development is much faster due to technological progress (EUROFER, 2013).

\section{NEW RISK FACTORS ON THE INTERNATIONAL MARKET}

There are new threats in the form of new risk factors emerging on the global markets in relation to dynamic development of metallurgy industry, problematic economic situation, long-term financial instability and other negative factors that were identified in the introduction of this article. These factors are mostly caused by the inappropriate interferences of governments into the market economy.

The most improper actions are in particular protectionism, subsidies and the effort to provide environmentally friendly production. In the last decades the markets became more open, the business barriers were removed, but the distortions of competition caused by non-transparent subsidy and protectionism in various fields unfortunately persist. There are a few on-going issues such as different 
environmental standards, direct financial support, tax exemptions, loan support, free infrastructure and land, subsidized energy and least but not last allocated tenders in advance (EUROFER, 2013).

Among the most important examples of subsidies belongs the support of Chinese government in metallurgical sector as well as its tendency to keep the artificial exchange rate of the currency. These factors reduce the competitiveness of other producers, and ultimately cause the loss of thousands of jobs and billions of dollars of investment in production and technology. Another factor that may significantly affect the economic characteristics of metallurgical companies is the European legislation highly regarding the environmentally friendly production.

Cooperation or partnership with the consumers may be a possible tool to minimize these impacts by means of implementation of technological innovations, which should be leading to positive economic and environmental effects. Boundary conditions valid for European steel producers are worsening due to two most important factors: carbon tax related to the reduction of $\mathrm{CO}_{2}$ since the year 2013 and the new Renewable energy law. Those factors make the situation even more dramatic.

The resulting additional costs lead to distortions of competition in comparison with direct competitors in other countries. European commitment to environmental protection is well meant, but it has to be based on a uniform set of global rules that do not diminish competition at the expense of the environment (METAL BULLETIN, 2013).

\section{DIFFERENCES OF BUSINESS MARKET}

To define the application of modern management trends in a very specific sector as the metallurgical industry certainly is the focus must be aimed at the analysis of current development changes of market environment as well as the recent trends in the dynamic environment of business markets.

The greatest difference is the fact that the receivers of this service are not the end consumers but another business subjects. The market consists of not large, but integrated customers with high volume demand; there is a geographical concentration of customers with very close supplier-customer relationships, demand is inelastic and dependent on consumer demand, purchases are professional, rational and bulk (KOZEL et al., 2011).

Purchase process happening on business markets is very complicated since there is a great influence of several groups of associates such as the purchase initiators, product users, final decision-making influencing factors, purchasers themselves and above all the decision-makers who are actually the most important in this whole process (without them the transactions cannot be made).

Therefore it is very essential for any company participating in business market to be perfectly aware of their customer needs and then be able to create and develop a long-term mutually beneficial relationship with them (VILAMOVÁ et al., 2011).

\section{SELECTED DEVELOPMENT TRENDS IN THE FIELD OF METALLURGIC COMPANIES' MANAGEMENT}

In the previous chapter the key differences of business markets were established. There are new trends in the metallurgical industry that are directly related to those differences. The business success in this competitive environment depends very much on efficiency and flexibility. The tense economic situation forces metallurgical companies to change the perspective of the strategic management and use new opportunities for marketing, management, business integration, networking and offshoring. 


\section{a) Marketing trends}

The key aspect on all markets is nowadays the customer satisfaction, which is more and more demanding. This fact brings the need to use the application of those marketing tools which will change and adapt according to the target customer, group and market.

The fundamental characteristic of the contemporary era of the world's economic development is dynamic globalization. There are other new factors affecting the success of firms operating in business markets, such as:

- Monitoring and consequential use of comparative advantages,

- Use of interactivity of economical subjects supported by modern technologies,

- Absolute necessity to focus on customer value,

- Monitoring and use of new integration trends in networking, strategic alliances etc.

The only company that can succeed within the competition in the global market is the one that can understand the needs of its customer in the whole process of development, production, sales, implementation and use of products. This basic assumption of success of the industrial enterprise is based on specifications of business markets and places, strong demand for differentiated approach to individual firms/customers through market segmentation and rigorous principles of relational marketing (MUDAMBI et al., 2009).

\section{b) Selected trends in management}

Specific nature of leadership tasks and responsibilities emphasise the need of structured tool for leadership competence management. Specifically tailored leaders will represent advantage for organizations (VUKOVIĆ et al., 2011).

Within the new trends in company management we have recently come across a new term: compliance. Growth of legal regulation, its high complexity and specialization, as well as requirements for expertise and narrow professional knowledge, along with the efforts to prevent breaches of generally binding legal regulations to ensure consumer protection, market transparency and equal competition, led to the creation of compliance function as an integral element of control system of various companies from many different fields.

This is an effort to find ways to transparent compliance with the law in practice and extension of ethics in society and especially in the corporate sector.

The fundamental function of compliance is securing and control of activities, and compliance especially of the corporate subject with generally obligatory legal regulations. Within this established legal framework the compliance officer search for optimal solution for each business plan and minimize the following risks: regulatory (sanctions), reputation (reputation damage) or other nature. Compliance is a new function and its importance and economic benefits not only for the business, grow in proportion to the increasing legislative requirements and complexity of legal regulations in various fields. This function represents extensive economic contribution to business in the field of prevention, searching for new approaches and everyday decision-making.

The compliance officer position is therefore highly vocational and very much appreciated. Preventive management of compliance is the assurance in the case of liability risk of the employees. In the longterm view it leads to the business value optimization. Apart from that the compliance management prevents the damage of strategic advantages in the economic competition (METAL BULLETIN, 2013). 


\section{c) Consolidation and networking opportunities}

The corporate sector is making all the efforts to maximize the productivity and minimize the costs. It seems that the consolidation is inevitable. The Japanese Nippon Metal Industry recently announced that its division will fuse with the same division of Nisshin Steel. There is also a rumour about conspicuous alliances of the European producers or joint ventures of European and Asian enterprises. One of the other ways to achieve greater competitiveness in the global business market is the networking or setting up alliances and acquisitions. These modern forms of integration are the most important issue of today.

So far it appeared that the basic function of these types of cooperation is strategic joint ventures of small and middle companies in the context of threats elimination impending form larger enterprises. Results of EQS modelling suggested that shared vision and resource sharing among network members significantly benefited members' businesses, and that these benefits were associated with generalized perception of the advantages of network membership and also positively affected members' future participation plans, thus furthering the likelihood of network continuance (MILLER et al., 2007).

The networking is becoming quite strong in the metallurgy industry in order to use the synergic effects, competitive advantages in the partner network, your partner's market knowledge, etc. Industrial firm boundaries are dynamic, changing with every new alliance or acquisition. As boundaries evolve, managers must develop organizational structures that effectively leverage knowledge (MUDAMBI $e t$ al., 2009).

At present the industry that use networking in the most profitable way is the automotive industry, however, the metallurgy is another field where these efforts can be effectively used. The largest independent wholesalers/service groups such as the German Kloeckner \& Co. are growing into huge acquisition and create large international multi-metal distribution and service networks. Large steel traders, such as Stemcor have also made strategic acquisitions of wholesalers and service centres this year (METAL BULLETIN, 2013).

\section{d) Offshoring}

The use of offshoring is another tool of modern business. It has been very much used to lower the operating costs of the industrial enterprises resulting from placing part of the business on a different continent. The reason for transferring some activities abroad is mostly the cheaper labour, but it can be also foreseen as the effort to get closer to the customers. In the field of industrial production it is possible to offshore almost every activity abroad.

\section{CONCLUSION}

Within the world's economy the metallurgy industry plays an important role: as the major industry it is placed at the beginning of the industrial value chain in many key sectors and thus creates a decisive contribution to international competitiveness. Steel companies with more than 3,5 million employees generate an annual turnover of 900 billion euros. The future starts with steel. Whether in the automotive sector, engineering, energy industry or the electronics the new steel and manufacturing technologies are the basic presumptions of innovative capacity and success.

A key aspect of the present in all markets has become the need of the best possible satisfaction of the needs of customers whose requirements keep growing. That fact incites the necessity to apply such corporate marketing tools which will develop and vary according to who is their target customer and, therefore, in which market they are applied. 
This paper presents the results of resources evaluation of the modern management trends application in the field of metallurgy, including the identification of specific areas of metallurgical companies in the context of a differentiated approach to the role of the customer as a potential positive competitiveness factor.

\section{REFERENCES}

EUROFER (2013). The European Steel Association. Brussels: Eurofer. Language version: EN. Available from www: <http://www.eurofer.org/>. Consulted 18. 10. 2013.

KOZEL, R., MYNÁŘOVÁ, L., SVOBODOVÁ, H. (2011) Moderní metody a techniky marketingového výzkumu. Praha: Grada Publishing.

ISBN 978-80-247-3527-6.

METAL BULLETIN (2013). Metal Bulletin. London: Metal Bulletin. Language version: EN. ISSN 0026-0533.

Available from www: <http://www. metalbulletin.com/>. Consulted 12. 8. 2013.

MILLER, N., J., BESSER, T., MALSHE, A. (2007) Strategic networking among small businesses in small US communities. International Small Business Journal, vol. 25, no.: 6, pp. 631-665. ISSN 0266-2426.

MUDAMBI, S., M., OLIVA, T. A., THOMAS, E., F. (2009) Industrial marketing firms and knowledge transfer. Industrial Marketing Management, vol. 38, no.: 2, pp. 181-190.

ISSN 0019-8501.

VILAMOVÁ, Š., JANOVSKÁ, K., VOZŇÁKOVÁ, I., KOZEL, R. (2011) Selected specific of marketing analysis and management in terms of industrial enterprises. Metal 2011, Ostrava: Tanger.

ISBN 978-80-87294-22-2.

VUKOVIĆ, A., IKONIĆ, M., DOBOVIČEK, S. (2011) Model for leadership competence management in metallurgical enterprise. METALURGIJA, vol. 50, no.: 3, pp. 167-171.

ISSN 0543-5846

WORLDSTEEL (2013). The Worldsteel Association. Brussels: Worldsteel. Language version: EN. Available from www: 〈http://www. worldsteel.org/>. Consulted 14. 11. 2013. 